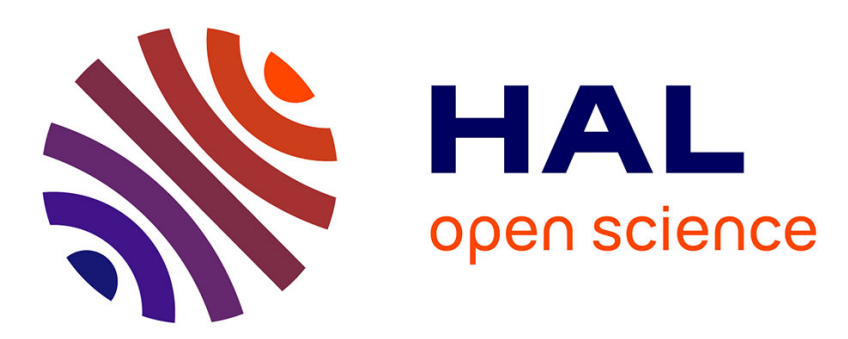

\title{
Public participation in environmental decision-making: a case study of ecosystem restoration in South Florida Laura Ogden
}

\section{To cite this version:}

Laura Ogden. Public participation in environmental decision-making: a case study of ecosystem restoration in South Florida. Cahiers d'Economie et de Sociologie Rurales, 2006, 80, pp.53-74. hal01201128

\section{HAL Id: hal-01201128 \\ https://hal.science/hal-01201128}

Submitted on 17 Sep 2015

HAL is a multi-disciplinary open access archive for the deposit and dissemination of scientific research documents, whether they are published or not. The documents may come from teaching and research institutions in France or abroad, or from public or private research centers.
L'archive ouverte pluridisciplinaire HAL, est destinée au dépôt et à la diffusion de documents scientifiques de niveau recherche, publiés ou non, émanant des établissements d'enseignement et de recherche français ou étrangers, des laboratoires publics ou privés. 


\section{Public participation in environmental decision-making: \\ A case study of ecosystem restoration in South Florida}

Laura OGDEN 


\title{
Laura OGDEN *
}

\section{Implication des citoyens dans les décisions publiques en matière de préservation de l'environnement: une étude de cas sur la restauration d'un écosystème dans le sud de la Floride}

\begin{abstract}
Résumé - L'approche en termes « d'écosystème » (entendue ici comme la variété des échelles spatiales et temporelles dans le cadre desquelles s'organisent les interrelations entre les habitats et les organismes) constitue le modèle conceptuel retenu pour guider les projets de restauration dans des Everglades, région marécageuse située au sud de la Floride. Estimée à 14,8 milliards de dollars, la restauration de ce milieu particulier représente l'un des projets environnementaux les plus importants et les plus onéreux jamais entrepris. L'article commence par une présentation des changements déjà intervenus et des interventions de restauration des milieux qui en ont découlé. Le cadre conceptuel guidant la gestion de l'écosytème est ensuite exposé ; l'auteur insiste sur son évolution et son institutionalisation à travers un ensemble de pratiques liées à la gestion et à la planification des opérations. L'article se termine par une analyse sur la façon dont la notion de «public» est conceptualisée dans le cadre d'une gestion institutionalisée de l'écosystème et par les prolongements de cette conceptualisation en ce qui concerne les décisions publiques en faveur de la restauration des Everglades.
\end{abstract}

Mots-clés : écosystème, participation publique, Everglades (Floride)

\section{Public participation in environmental decision-making: a case study of ecosystem restoration in South Florida}

Summary - The "ecosystem" is the conceptual model guiding environmental restoration projects in the Florida Everglades, a large wetlands region in the southern United States. According to applied ecological frameworks, ecosystems are geographies (of various temporal and spatial scales) where systemic interrelationships of organisms and babitat occur. With current project estimates at 14.8 billion dollars, ecosystem restoration in South Florida represents one of the largest and most expensive environmental projects ever attempted. In this article, I provide an overview of the changes to the Florida Everglades which have led to the need for restorative interventions. I then outline the conceptual framework guiding ecosystem management in South Florida, focusing on the transformation of this framework that occurs through its institutionalization into a set of management and planning practices. The article ends with a discussion of how the "public" is conceptualized within this institutionalized ecosystem management framework, and the ramifications of this conceptualization for Everglades restoration public engagement activities.

Key-words : ecosystem, public participation, Everglades (Florida)

\footnotetext{
* Department of Sociology/Anthropology, University Park Campus, Florida International University, Miami, Florida 33199, United States e-mail : ogdenl@fiu.edu
} 


\section{Ecosystems and the politics of nature}

In the United States, ecosystem approaches have become the predominant model for landscape-scale environmental planning, restoration and management. Numerous examples attest to the primacy of applied ecosystem science within environmental policy - from Chesapeake Bay restoration initiatives on the East Coast to the Pacific Northwest's forest and timber management programs (Gunderson, 2003). Spanning 18,000 square miles (3.6 million hectares), with a projected cost of $\$ 14.8$ billion, the Everglades restoration program in Southern Florida represents one of the most comprehensive of such efforts in both scale and scope (SFERTF, 2002), and for the purposes of this examination, serves as a case study exploring the application of ecological theory within a highly bureaucratized institutional context. In particular, I examine the process by which government agencies leading the restoration effort shape our understanding of the boundaries and characteristics of the Everglades as an ecosystem. In this bureaucratized context, the theory and practice of ecosystem management has been considerably narrowed, reflecting the lead agencies' missions and traditional areas of expertise. Furthermore, this constriction, I demonstrate, imposes barriers on the public's ability to participate in restoration decision making.

As an anthropologist, I am particularly interested in how humans are positioned within various visions of the "natural" world (whether "environment," "ecosystem," "wilderness", or "landscape"). While these metaphors of nature disclose entangled cultural and philosophical histories, they become institutionalized into an array of practices by policymakers when treated as management "approaches" or "principles." Anthropologists have both embraced and criticized the adoption of the ecosystem approach as a way of thinking through human/environmental relationships (Rappaport, 1967 and 1990; Netting, 1990; Kottack, 1999; Moran, 1990; Spooner, 1987; Bennett, 1990; Godelier, 1986). While weighing in on this debate, I hope to contribute to broader theoretical investigations into the "politics of nature" by exploring the ways in which the public is characterized as the ecosystem concept becomes institutionalized into a set of management practices and, moreover, how this characterization affects the public's ability to participate in environmental decision-making. The politics of nature that this article investigates includes not only the formal politics of state administrative agencies, and the internal politics by which they function, but also, and perhaps more importantly, the discursive power of bureaucratized ideas of nature to shape the character of environmental decisionmaking.

To investigate this process, I have conducted ethnographic interviews with regional stakeholders and natural scientists, observed restoration planning meetings and public outreach forum, as well as analyzed the proliferation of official documents which articulate state agency goals, missions, and funding for Everglades restoration programs. In addition, I have spent several years working with participating government agencies to develop social science plans and policy for Everglades restoration. In this article, I first provide an overview of the changes to the Florida Everglades which have led to the need for restorative interventions. I then outline the conceptual framework guiding ecosystem management in South Florida, focusing on 
the transformation of this framework that occurs through its institutionalization into a set of management and planning practices. The article ends with a discussion of how the "public" is conceptualized within this institutionalized framework, and the ramifications of this conceptualization for Everglades restoration public engagement activities.

\section{The Everglades: A history of transformation}

Everglades National Park is located at the southern end of peninsular Florida. Though now included on the UNESCO List of World Heritage in Danger, the park continues to offer visitors a chance to experience the least altered portion of Florida's once vast subtropical wilderness. Within the park's boundaries lies the largest continuous stand of sawgrass prairie and the most significant breeding ground for tropical wading birds in North America, as well as the largest mangrove forest in the western hemisphere. Yet the national park represents only a portion of the Everglades wetlands system, as presented in figure 1 - which begins just south of Orlando (the location of Disney World) and extends southward through a series of lakes, freshwater marshes, tree island hammocks, cypress and mangrove swamps, to the waters of Florida Bay and other estuarine lagoons (Ogden J. et al., 2003).

Figure 1. The historic Everglades watershed and current boundary of the restoration program, satellite image courtesy of the SFWMD.

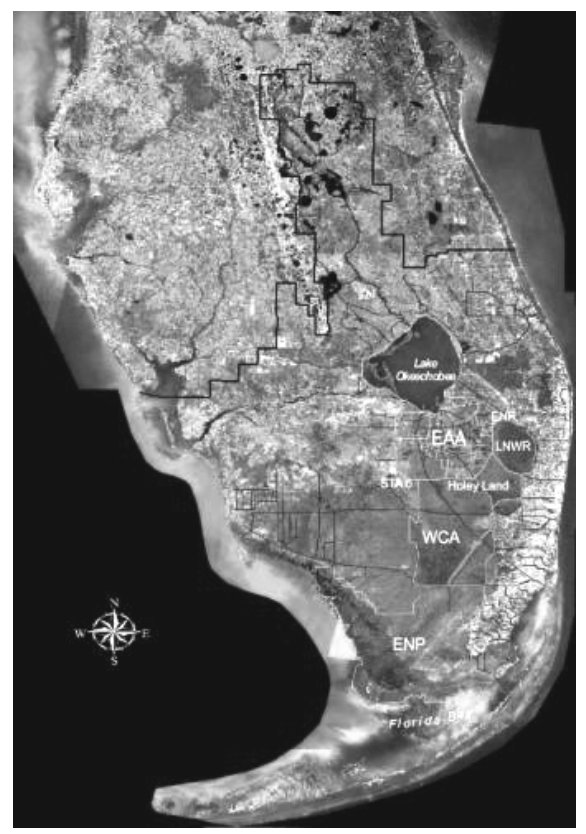

With a population of 7.5 million people, the Everglades' social landscape is equally complex. The region spans vast expanses of agricultural farmland (such as the Everglades Agricultural Area or "EAA"), rural towns, as well as a sprawling metropolitan eastern corridor that culminates in the City of Miami. South Florida's demographic characteristics include increasing in-migration, high percentages of elderly and seasonal residents, as well as areas where Spanish-speaking residents constitute the majority (such as Miami Dade County). Drive an hour in any direction across the region, and one cannot help but be struck by the disparity between the obvious excesses of conspicuous consumption (Hummer stretchlimousines, gated communities that redefine the notion of exclusivity) and economic vulnerability (rural migrant work camps, block after block of plywoodshuttered houses and storefronts throughout the urban centers). 
Historically, government-facilitated drainage initiatives spurred increased settlement in the Everglades. After acquiring statehood in 1845, the Florida legislature quickly passed several laws to encourage Everglades drainage, otherwise known as "reclamation," for the purposes of agricultural and urban development ${ }^{1}$. Yet $19^{\text {th }}$ century drainage efforts pale in comparison to the water management policy of the post-World War II years. After a series of devastating and disastrous hurricanes and floods, the federal government authorized a massive flood control and water management project known as the Central and Southern Florida Project $(\mathrm{C}$ and SF Project) in $1948^{2}$. Implementation of the $\mathrm{C}$ and SF Project continues today and includes one thousand miles of levees and canals, 15 square miles of interconnected water reservoirs, 150 water control structures, and sixteen major pump stations. Essentially, the C and SF Project transformed the Everglades into one of the world's largest and most expensive "plumbing" systems. Originally designed for a maximum population of two million, the $\mathrm{C}$ and SF Project now provides flood control and water supply for three times that number.

Yet even as the dredging machines plowed forward, concerned citizens and scientists lobbied relentlessly for the protection of local landscapes and wildlife in the Everglades (Small, 1929; Simpson, 1923; McCally, 1999; Tebeau, 1968). Responding to this pressure, federal and state agencies initiated a parallel, though contradictory, approach to managing the Everglades. While encouraging Everglades drainage, at the same time governmental funding and programs were directed toward the conservation of remnant portions of that system. For instance in 1947, the year prior to Congress authorized the $\mathrm{C}$ and SF Project, land was set aside for the establishment of Everglades National Park (Tebeau, 1968). These policy contradictions embody well-known western philosophical traditions imbricating "natural" and "human" landscapes (Arnold, 1996; Ellen, 1996; Olwig, 2001; Williams, 1980; Bender, 1993, 1999, 2002). In South Florida, drained and developed portions of the Everglades (manifestations of culture and progress) were managed to meet the region's increasing water demand and flood control needs, with natural areas treated as discrete entities managed to protect native habitat and species. Moreover, and this becomes important for the contemporary restoration context, specific federal agencies were assigned administrative oversight over these different Everglades, with the US Army Corps of Engineers managing the construction of the $\mathrm{C}$ and SF Project and agencies from the Department of the Interior (such as the National Park Service) managing lands and resources deemed natural.

Of course, both the scientific and environmentalist communities understood that drainage, the introduction of agricultural and industrial contaminants, as well as unnatural hydrologic cycles were having devastating consequences. For instance,

1 See McCally (1999) for discussion of early Everglades drainage policy and activity; Hollander (2004) for history and policy of sugar cane farming in the Northern Everglades.

2 In particular, two hurricanes struck the farming communities around Lake Okeechobee, Florida during the 1920s. In 1926, 13,000 homes and farms were destroyed along the lake's eastern edge, leaving over 400 dead. Two years later, another hurricane struck the region causing the earthen dike around the lake to fail. In an hour's time, over 2,000 people, many of them African-American farm workers, drown in the rushing waters. 
ornithological records suggest that the region's famous wading bird populations have been reduced by 90 to 95 percent since the pre-drainage era (Ogden, 1994). This loss is as much historically as ecologically significant, as it was the region's rookeries that first lured naturalists to the area, establishing the Everglades as a landscape of national significance. Most dramatically has been the development of 2/3's of the Everglades, with this loss of land particularly critical to larger mammals, such as the endangered Florida panther, which require vast habitats for breeding. In all, 68 native Everglades plant and animal species are listed as endangered or threatened.

These changes have also impacted human populations in South Florida. To provide adequate flood control, each day an average of 1.7 billion gallons of freshwater is diverted to the oceans and bays, causing repeated water shortages and saltwater intrusion to the aquifer. Residents have experienced dramatically declining populations of commercially important fish and other seafood, such as pink shrimp. And currently, one million acres of land and waterways are under health advisories for mercury contamination, impacting subsistence fisheries. In response to these problems, the US Congress authorized the Comprehensive Everglades Restoration Plan ("restoration plan") in 2001, earmarking $\$ 8.9$ billion dollars for restoration efforts in South Florida ${ }^{3}$. Much of the funding will be spent on complex engineering projects designed to store, retrieve and manage water to meet current and future human and environmental needs 4 .

\section{The human dimensions of the Everglades ecosystem}

There are several thorough disciplinary histories of ecosystem ecology, including those by Cortner and Moote (1999), Golley (1993) and, of broader disciplinary scope, Worster (1977). Suffice to say, ecologists and other scientists understand and apply the ecosystem concept differently depending upon their research interests, theoretical orientations, and association with various national and international research and academic institutions (Golley, 1993; Worster, 1977). Still, the term commonly is used as a heuristic device to think through the relationships between habitats and organisms, often sharing a number of implicit theoretical assumptions. The first of these assumptions is that the natural world contains identifiable ecological boundaries, albeit permeable boundaries, where systemic interactions between the physical environment and local biota take place. Second, these interactions produce an entity (the "ecosystem") whose overall properties are different than the assemblage of its parts. This philosophical bolism requires scientists to conceptualize ecosystems not as static

3 The Comprehensive Everglades Restoration Plan, which is locally and by bureaucratic tradition referred to as CERP, is only one component of the total South Florida ecosystem restoration program, though CERP is the largest and is estimated to cost $\$ 8.9$ billion. Total program components are estimated to cost approximately $\$ 14.8$ billion (SFERTF, 2002). To avoid unnecessary jargon, I am using the phrase "restoration plan" when referring to CERP and "restoration program" when referring to the total Everglades restoration effort.

4 For additional information about the history and project components of the Comprehensive Everglades Restoration Plan, see www.evergladesplan.org. 
functionalist machines, but adaptable, resilient systems that gravitate toward states of internal homeostasis (Golley, 1993; Jorgensen and Muller, 2000; Moran, 1990).

Even with these theoretical assumptions, the ecosystem concept is elastic enough to accommodate the study of nature at a variety of scales (geographic and temporal), and degree of biophysical complexity (from total system interactions of hydrology and habitats to chemical and nutrient cycling at much smaller scales). This elasticity and macroscopic focus accounts for the concept's application to a variety of disparate environmental planning, restoration, and management contexts throughout the United States (Gunderson, 2003). In the transition from theory to practice, two complementary management principles typically provide a framework for environmental decisionmaking. First, organisms and environments are assumed to be interrelated at ecoregional scales, therefore ecological data and assumptions (as well as adaptive assessment strategies) should to be incorporated into regional water management and environmental planning activities (Busch and Trexler, 2003; Jorgensen and Muller, 2000; Ogden J. et al., 2003). Second, accounting for and predicting environmental change requires developing scientific frameworks and management scenarios that treat landscapes as complex socio-ecological systems (Redman et al., 2004; Berkes and Folke, 1998; Berkes, 2004) ${ }^{5}$. For clarity's sake, I refer to this management framework, broadly speaking, as the "ecosystem approach."

The ecosystem approach is reflected in the Comprehensive Everglades Restoration Plan which the United States Congress passed in 2001. In the ratification of the restoration plan, Congress set planning and science policy by specifically mandating that the restoration plan be developed and implemented using the principles of ecosystem management. Restoration planning documents developed in response to the congressional mandate echo the inclusive approach common to contemporary ecosystem ecology. For instance, the overarching restoration strategy is described as management with a "systemwide perspective," accomplished by seeking out the "interrelationships and mutual dependencies that exist between all the components of the ecosystem" (SFERTF, 2002, vi). Moreover, the idea that the built and nonbuilt environments are "inextricably linked," and thus mutually interdependent, is repeated throughout governmental planning and strategy documents which outline restoration principles (SFERTF, 2002; USACE and SFWMD, 1999).

Yet, in practice, with the exception of water management planning, there has been little consideration of the human dimensions of the Everglades ecosystem in the restoration planning process. The difficulties of incorporating social science research into ecosystem modeling and planning scenarios are widespread, and discussed at length elsewhere (see Moran, 1990, for overview). These difficulties

5 In the United States, the shift in applied ecology toward theorizing the complexity of coupled human and natural systems is gaining increasing momentum within academics and natural resource management agencies. For instance, the National Science Foundation's LongTerm Ecological Research Program, of which I am a collaborator, is currently developing recommendations for an "Integrative Science for Society and the Environment," as part of an ambitious two-year planning process. The effort identifies programmatic frameworks which link fundamental investigations of society and the biophysical environment. 
include disciplinary boundaries which have posed intellectual and communication barriers between natural and social scientists (Gragson and Grove, 2006; Redman et al., 2004); problems of scale mismatches between ecological and social systems (Cumming et al., 2006); and a mistrust by social scientists of the "old" ecology's perceived functionalism (Abel and Stepp, 2003). These barriers are certainly not non-existent within the dialogic process of theorizing the Everglades as a socio-ecological system. Yet in the eight years that I have been involved in Everglades and restoration-related social science research and planning, my ecological science colleagues, almost across the board, have recognized and articulated the need for incorporating socio-economic variables and data into restoration conceptual models and adaptive management strategies. Instead, the problem seems to lie less with an intellectual unwillingness to produce "socio-ecological" research, than in the way in which restoration architects have conceptualized "ecosystem management" and the institutional barriers resulting from this paradigm, as I discuss below.

The restoration plan emerged as a result of a congressionally mandated reexamination of the $C$ and SF Project, which scientific and political consensus deemed responsible for much of the region's environmental problems. From 1992 until 1999, the United States Army Corps of Engineers ("Corps") led the effort to develop a plan for modifying the $C$ and SF Project, involving the input of hundreds of hydrologists, ecologists and other biophysical scientists, engineers and a variety of interested stakeholders (such as public utilities, farmers, environmental organizations). The plan which resulted from this process (called the "Restudy") is less a plan for environmental restoration than a plan to re-engineer the $C$ and SF Project water management system. What distinguishes this effort from previous regional-scale water management planning efforts is that the plan uses an ecosystem management approach to mitigate past environmental problems (such as habitat fragmentation and detrimental hydrologic cycles) and to develop a new water management system that will provide future environmental benefits. Here, ecosystem management is a component of an incredibly complex, highly-technical water supply, delivery and storage plan — rather than water management conceptualized as a tool within a broader ecosystem management framework. This conceptualization of the role of ecosystem management has produced institutional barriers to addressing the human dimensions of the ecosystem and developing a socio-ecological ecosystem approach.

The lead agencies in charge of restoration planning and implementation reflect the restoration plan's water management and engineering focus. The Corps, the original architect of the $\mathrm{C}$ and SF Project, serves as the federal partner for the restoration plan, while the South Florida Water Management District ("District"), the agency tasked with managing the $\mathrm{C}$ and SF Project, serves as the lead agency for the State of Florida. Both of these agencies epitomize the "command and control" managerial approach which Holling and Meffe argue "permeates much of natural resource management" (1996, p. 329). Underlying this approach is the certainty that problems can be solved by controlling their underlying processes, even when these processes are poorly understood, hard to predict, non-linear and complex in 
nature ${ }^{6}$. The emerging literature on US natural resource agencies suggest that, like most bureaucracies, the most successful agencies (defined in terms of budgets, staffing, and public support) are those which are able to stake out specific terrains of expertise and defend them (Clarke and McCool, 1996). The Corps and the District have staked out a watery terrain, with their expertise granted through their ability to control these resources.

Current restoration budgets suggest that the agencies who once had the greatest stake in making decisions about the Everglades are the same agencies who now have a considerable stake in its restoration. Eighteen federal departments and/or agencies are involved in restoration planning and implementation, though the Corps and agencies within the Department of the Interior (specifically the National Park Service and the Fish and Wildlife Service) receive the vast majority of federal funds allocated for restoration programs. For instance, in 2005 federal restoration-related budgets totaled $\$ 270$ million, with approximately $\$ 125$ million allocated to the Corps and $\$ 106$ million to agencies within the Department of the Interior (SFERTF, 2005). Historically, the Corps' expertise, strategic vision and mission have not supported research directed toward the complexities of the human dynamics of the environment. Instead, the Corps primary "environmental" activities have been to provide engineering solutions for a variety of environmental problems - ranging from shoreline protection programs, harbor and waterway navigation concerns, disaster assistance, and environmental restoration projects ${ }^{7}$. Agencies within the Department of the Interior, reflecting their mandates and missions, have focused their research and management activities toward environmental stewardship and resource management issues as they relate to the restoration plan. Therefore, the expertise and staffing that restoration funding supports ensures that the paradigm for Everglades restoration has an engineering, water management, and eco-centric focus ${ }^{8}$. In an interview, I asked a restoration planner to explain the lack of socioeconomic research in the restoration plan, the person said, "It's not big macho engineering that the Corps... relates to and does."

In fact, since the restoration plan was authorized no governmental agency has conducted research or provided policy recommendations reflecting an integrated socioecological approach to ecosystem management - with the exception of projections and

6 An anonymous reviewer of this paper suggested the relevancy of the Holling and Meffe (1996) to this discussion, for which I am grateful.

7 For additional information on the Corps projects and mission, see www.hq.usace.army.mil. The Jacksonville District of the Corps' South Atlantic Division oversees Everglades restoration activities, see www.saj.usace.army.mil for additional information. See Shallat (1994) and Clarke and $\mathrm{McCool}$ (1996) for histories of the Corps.

8 There are government institutions participating in restoration activities that have missions substantially addressing the economic and social dynamics of environmental change, including the United States Department of Agriculture, the Bureau of Indian Affairs (within the Department of the Interior), and the United States Environmental Protection Agency. Even so, these agencies' restoration funding and associated activities are directed toward supporting the restoration program's natural resource and water management goals. For instance, the US Department of Agriculture's Agricultural Research Service (ARS) applies its funding ( $\$ 4,421,000$ in 2005) to develop "improved scientific technologies and enhanced management strategies" which promote "sustainable agriculture as it complements" the restoration plan (SFERTF, 2005:16). 
economic modeling of regional water demands and use. The National Research Council (NRC), an independent advisory board for the US National Academy of Sciences, has repeatedly warned of the consequences of ignoring social and economic issues in restoration planning (NRC, 2003; CROGEE, 2003), and a review panel of fifty social scientists cited critical information gaps including a "full-cost" accounting of the costs and benefits of restoration to various communities and economic sectors (SFERWG, 1999). In a review of restoration science, the NRC noted that while anthropogenic drivers are essential components of ecosystem conceptual models, the research to develop these variables has been "modest" with socioeconomic science having had "little impact on restoration decision-making" (NRC, 2003, p. 67).

It would be egregious to suggest that social and economic variables are not included in the restoration plan when the paradigmatic focus of the plan is regional water management. At the same time, these water management objectives seem to have effaced consideration of all other facets of the ecosystem's humanity. Clearly, an adequate and clean water supply, flood protection, and healthy natural areas are critical socioeconomic concerns and priorities. Yet these are not the only human dimensions of the ecosystem necessary for restoration success. For instance, "mutually interdependent" ecosystem issues not captured by restoration planning and research include the sustainability of agriculture (necessary for the protection of green space), air and noise pollution, demographic trends (including changes in global immigration patterns), non-market and market evaluations of restoration activities and natural resources, transportation planning, and, perhaps most importantly, the political economy of regional land use change.

Ecosystem management, as I have argued, serves as an adjunct to the larger project and goal of redesigning the region's water supply, storage and distribution system. The agencies leading the restoration effort reflect the primacy of the restoration project's water management objectives. Within this context, the role of ecosystem management is to shape the re-engineered $\mathrm{C}$ and $\mathrm{SF}$ Project to mitigate for past environmental problems, and hopefully, to provide future environmental benefits. Consequently, the human dimensions of the Everglades ecosystem have been reduced to issues of water demand, water use and flood control. In other words, this modified ecosystem approach to addressing human and non-human interrelationships across biophysical space has been considerably narrowed within the institutional and intellectual framework of the restoration program. No where has this structural circumscription been more apparent than in public engagement efforts for Everglades restoration.

\section{Public engagement and ecosystem restoration: Which public participates 9 ?}

Traditionally, in the United States natural resource managers have privileged expert over "local" knowledge in planning and policy making, relying minimally on

9 I appreciate the assistance of my colleague Daniel Dustin in the review and summary of the public engagement literature discussed in this section. This review stems from a report we were co-authors on (Ogden L. et al., 2003). All critical commentary on Everglades public engagement strategies reflects my own research and findings. 
the general public for input (Steelman, 2001). As environmental justice advocates have noted, these expertise-driven planning approaches tend to exclude entire segments of the general public from the process, particularly minority and/or economically disadvantaged groups (Dennis, 1988). These excluded groups are also those who typically endure a disproportionately large share of the negative consequences associated with the implementation of environment planning and policy decisions (Cole and Foster, 2001). In recent years, due in part to a need to reduce social conflict and litigation, the planning paradigm has shifted to give the general public greater input in natural resource decisions (Gunderson, 1995 ; Dustin and Schneider, 1998 ; Steelman, 2001) ${ }^{10}$.

Even with these shifts in policy and attitude, there continue to be a number of barriers to a successful transition to a more inclusive decision-making framework. They range from a lack of trust in government (Krannich and Smith, 1998), to administrative and judicial constraints (Moote et al., 1997 ; Moote and McClaran, 1997), to figuring out which are the most effective public engagement methods (Gregory et al., 2001 ; Glicken, 2000 ; Webler et al., 2001). Research indicates that the most often documented source of failure of public engagement is resistance by agency decision-makers to meaningful public input (Lawrence and Daniels, 1996). While in theory agencies may profess support of public input, the literature suggests that this support is actually for public education programs rather than for developing a cooperative decision-making framework.

Though meaningful public engagement in environmental decision-making is always difficult, in South Florida one of the greatest obstacles to incorporating public engagement strategies into restoration planning and implementation (and sociocultural research, in general) may be the institutionally-defined emphasis of the restoration plan's ecosystem approach. In trying to understand the dynamics of change and resilience over time, ecologists generally differentiate between ecological and human drivers to ecosystems (Redman et al., 2004), with human activities often conceptualized as external impacts to the natural world. Scientists engaged in restoration planning in South Florida, lacking the institutional support and research to do otherwise, have adopted this traditional ecological model of human and nonhuman interactions. For instance, conceptual models guiding restoration planning posit human activities as external "drivers" to the natural system (Ogden et al., 2005), rather than conceptualizing human behavior and perceptions as integral components of a dynamic system. In South Florida, these human impacts include

10 Federal and State statute and precedent, including the CERP's enabling legislation, reflect these tendencies and provide a legal framework for protecting the public's welfare in the decision-making process. The Florida Sunshine Law, the Presidential Executive Order on Environmental Justice, and the National Environmental Policy Act of 1969 (NEPA) are but a few of the laws designed to promote and protect the public welfare in the decision-making process. The Water Resources and Development Acts specifically call for public involvement in South Florida ecosystem restoration. In addition, the American Indian Religious Freedom Act, the Native American Grave Protection and Repatriation Act, and the National Preservation Act all call for greater involvement of Native Americans and other groups in the review of public projects. 
water supply and flood control demands, alterations in water quality linked to pollutants and nutrients, demographic pressures on undeveloped lands, and the introduction of exotic species, among others.

Mirroring this conceptual framing of human/ecosystem dynamics, the "public" actively engaged in restoration decision-making and policy formation are those sectors viewed by policy-makers as having a stake (primarily an impact) on the natural system. These sectors include utility companies, real estate interests, zoning boards, commercial agriculture, and resource users (such as fishing and hunting organizations). Environmental non-governmental organizations represent the sole exception to this stakeholder impact model. As these public sectors are obviously stakeholders in restoration outcomes, restoration agencies assiduously include these groups in a variety of consensus-building forums and procedures. For instance, the restoration plan's conceptual stage included an extensive series of public forum and focus groups designed to elicit input from "targeted stakeholders" (USACE, 1999). Not only do these public sectors engaged in restoration planning recognize that they have a material stake in the process and outcomes, they also have the economic and political capital to affect change.

The Governor's Commission ("Commission") for a Sustainable South Florida represents a classic example of the "targeted stakeholder" model of public engagement which has guided restoration planning. Former Florida Governor Lawton Chiles established the Commission in 1994 to develop recommendations for "regaining a healthy Everglades ecosystem with a sustainable economy and quality communities" (GCSSF, 1995). The Commission's membership included approximately 50 representatives from a variety of governmental agencies and offices (municipal, regional, tribal and state representatives), farming sectors, public utilities, real estate development concerns, as well as environmental organizations ${ }^{11}$. One of the Commission's primary tasks was to serve in an advisory capacity to the Restudy process (the interagency program for developing the restoration plan, led by the Corps of Engineers). The Commission's recommendations certainly influenced the outcome of the restoration plan (see GCSSF, 1996) and served as the principle vehicle for channeling nonagency recommendations into the restoration planning process. Yet during the two years I worked as a staff member on the Commission there were very few instances in which people without a clear economic stake in the restoration process participated in public comment opportunities at Commission meetings. The only exception was during debate over restoring water flow into a region of the Everglades where the options included condemning and flooding an existing rural neighborhood.

Throughout various public engagement venues, from small-sized community forums to the formal Commission meetings, minority and economically vulnerable communities have had very little input into restoration planning. For example, multinational corporations engaged in sugarcane production have had enormous

11 See www.state.fl.us/everglades/gcssf/gcssf-reports.html for archived documents developed by the Governor's Commission for a Sustainable South Florida. From 1997 through 1999, I served on the Commission staff through a position funded jointly by the United States Environmental Protection Agency and the Society for Applied Anthropology. 
power to delineate acceptable restoration policy (Roberts, 1999), while migrant farm workers have been largely absent from community meetings, formal stakeholder organizations, and the like. Locally, the long-term effects of restoration programs will certainly include changes in regional land use and planning (with related equity, gentrification, and housing market impacts); access to natural resources for recreational, subsistence, and commercial purposes; as well as a restructuring of agriculture (raising questions about the industry's future sustainability and the corresponding impacts on documented and non-documented workers). While everyone in the United States has a stake in publicly-funded initiatives, it appears that communities most vulnerable to the restoration program's potential social and economic impacts are the least aware of the program's scope or goals.

Though restoration-focused public perceptions research has been limited, our findings indicate that the general public has very little knowledge of the Everglades ecosystem, the current water problems in South Florida, or the restoration plan itself (Ogden L. et al., 2003; Milon and Hodges, 2000). Indeed, polling suggests that groups absent from restoration planning activities are those with the least knowledge of restoration initiatives. For instance, a telephone survey conducted for the District revealed that 68 percent of those surveyed identified themselves as being "just a little bit" or "not at all" familiar with the restoration plan (Conway, 2004). In a more nuanced survey, conducted by Clemson University for the National Park Service, 55 percent of respondents were unaware of the restoration plan (Bransford et al., 2006). Respondents lacking familiarity with the restoration plan described themselves as being younger, having lower incomes, recent immigrants, speaking a language other than English at home, urban dwellers, non-homeowners, African-American, and "neutral" on the environment.

The complexity of attitudes about the Everglades and restoration became clear during a community forum on Everglades restoration that I, as a member of a social science research team, facilitated in Miami in June of $2003^{12}$. Fifteen representatives from civic and non-governmental organizations in urban Miami, principally social service providers, participated in the forum which included an overview of Everglades restoration activities, followed by focus group interviewing and discussion. One insight gained from this forum was that while resource managers generally consider the Everglades an "ecological" place, or a system of water, for many South Florida residents the Everglades evokes strong emotional, historical and economic associations.

Moreover, the majority of participants' perceptions of the Everglades were negative - a hostile, uninviting environment, which some equated with past injustices, such as slavery. We learned that forum participants had very little knowledge about the

12 The Community Forum was part of a larger research project entitled "Public Participation and Engagement in Ecosystem Restoration Planning and Implementation: A Guide for Resource Managers," funded through the US Department of the Interior's Critical Ecosystem Studies Initiative, under a cooperative agreement with the National Park Service, Everglades National Park ( $\mathrm{n}^{\circ}$ 1443CA5280-010016. Project researchers were Kenneth Lipartito (Project Manager), Laura Ogden, Mahedev Bhat, Daniel Dustin, and Hugh Gladwin (Co-Principle investigators). 
Everglades ecosystem, current water problems in South Florida, or restoration initiatives and goals. Those who had some knowledge of Everglades restoration viewed the purpose of the plan as "saving wildlife" and only one participant (who was involved in a local environmental group) seemed to understand the human dimensions of the issues. Though forum participants were long-time residents and activists, few had visited the Everglades nor were participants aware that much of greater Miami is located on former wetlands (Ogden L. et al., 2003). Notably, even the participant representing a local urban environmental organization had no desire to visit the Everglades.

The only real conclusion we can draw from this initial research is that South Florida residents who have the least knowledge of restoration initiatives also are the least likely to be involved in restoration planning. Certainly, the demographics of participants in Everglades restoration planning reflect trends throughout the United States. For example, evaluations of public engagement programs in the US Forest Service found that participants tended to be well-educated, have relatively high incomes, and be more politically conservative than the general public (Lawrence and Daniels, 1996). In the case of Everglades restoration, those disengaged from the process may be so because they do not realize they have a stake, perceiving Everglades restoration as solely related to environmental protection efforts. What we can conclude, with some certainty, is that current public outreach, engagement, and education strategies have not reached the region's most vulnerable populations - such as the poor, recent immigrants, and the less educated.

Instead, those with a clear economic stake in restoration outcomes have been "targeted" to participate in a variety of restoration-planning forum. These targeted stakeholders are the same groups, by and large, that the restoration program's guiding paradigm designates as having an impact on the natural or water management systems. To develop engagement and awareness programs to reach those who do not realize they have a stake, first, will require research and analyses of the stakes various constituencies have in restoration outcomes, both positive and negative. At this point, reflecting the dominant paradigm of restoration, we have scant understanding of the social and economic dimensions of Everglades restoration. Without this information we cannot begin to develop appropriate engagement strategies which "target" those currently disengaged from the process. Of course, reconceptualizing the Everglades as a complex coupled human and natural system entails a considerable paradigm shift by restoration planners and the incorporation of integrative research that addresses this complexity.

\section{Discussion}

Importantly, the ecosystem approach has offered resource managers a critical lens for thinking through South Florida's complex ecological relationships at a regional scale. Moreover, the approach has facilitated the unprecedented incorporation of ecological science in local water and land management practices. In no way do I wish to diminish the importance of this effort - as the region's history of development and drainage has left the Everglades on the verge of ecological collapse. Yet at the same time, translating the ecosystem concept into an institutionalized management 
approach by administrative agencies has presented structural and intellectual barriers to addressing societal concerns and equitable public engagement into Everglades restoration planning.

Environmental anthropologists and sociologists have explored the ways in which states exercise their power by setting bureaucratic and legal boundaries on various ways of thinking about and acting upon nature, often calling upon scientific and technical knowledge to defend these claims (Guha, 1989; Peluso, 1992 and 2003; Fairhead and Leach, 1996; Neumann, 1998 and 2004). But states, like the cultures and places they seek to engineer, are hardly monolithic entities (Abrams, 1988; Li, 2005; Moore, 2005). Instead, modern states control resources and peoples through a profoundly complex architecture of administrative agencies, quasi-governmental organizations, and a variety of nested and overlapping private/public partnerships. These institutional contexts are sites of political contest, having their own cultures, histories, and terrains of expertise to defend and stake out.

The pathways by which scientific knowledge proceeds to inform claims of state authority depend upon these institutional cultures. The scientific and expert knowledge that state institutions utilize to justify policy decisions and management initiatives reflects the fragmented bureaucratic contexts where it is produced, adopted, and/or transformed. Sheila Jasanoff reminds us that science "embeds and is embedded" into a myriad of social and institutional practices and conventions (2004, p. 3). In the case of Everglades restoration, the ecosystem approach appears on paper and in law to provide an integrated framework for considering the complexities of the region's human-ecological system, reflecting the direction of contemporary ecological theory. Yet, institutionalizing the ecosystem approach substantially circumscribed and transformed it into a strategy for mitigating the environmental impacts of a regional water management program. Like many paradigms or ideas borrowed from the natural sciences, the ecosystem concept appears strikingly apolitical. Yet, as this case study suggests, the politics of ecosystem management reside in the institutional contexts by which they are embedded.

Details of the restoration plan's project components continue to be refined, but the logic of the restoration plan asserts that Everglades restoration requires, in part, a re-engineering of the Southern and Central Florida Project. Long-term restoration success will depend upon the public's support and engagement in restoration decision-making. For this to occur, engagement strategies need to reach community members who may not know that they too have a stake in restoration outcomes. But initiating appropriate and effective public engagement programs first requires the development of baseline data on the public's perceptions and awareness of Everglades restoration programs and integration of social and economic research into the framework of restoration planning and long-term adaptive management strategies. Furthermore, it requires a re-conceptualization of who actually has a "stake" in the restoration plan, and subsequently, a reappraisal of the appropriate agencies to involve in administering the restoration program. This research suggests both a need to reevaluate the efficacy of current engagement materials and practices, and in a larger sense, the institutional resources available for developing such programs. 


\section{References}

Abel T., Stepp R. (2003). A new ecosystem ecology for anthropology, Conservation Ecology, vol. 7, p. 12.

Abrams P. (1988) [1977]. Notes on the difficulty of studying the state, Journal of Historical Sociology, vol. 1, pp. 58-89.

Arnold D. (1996). The Problem of Nature : Environment, Culture and European Expansion, Oxford, Blackwell.

Bender B. (2002). Time and landscape, Current Anthropology, vol. 43 (Suppl.), pp. S103-112.

Bender B. (1999). Subverting the western gaze: Mapping alternative worlds, in: The Archaeology and Anthropology of Landscape: Shaping Your Landscape, Ucko P.J., Layton R. (eds), London, Routledge.

Bender B. (ed.) (1993). Introduction: Landscape-meaning and action, in: Landscape: Politics and Perspectives, Oxford, Berg.

Bennett J.W. (1990). Ecosystems, environmentalism, resource conservation, and anthropological research, in: The Ecosystem Approach in Anthropology: From Concept to Practice, Moran E.F. (ed.), Ann Arbor, MI, The University of Michigan Press.

Berkes F. (2004). Rethinking community-based conservation, Conservation Biology, vol. 19, pp. 621-630.

Berkes F., Folke E. (eds) (1998). Linking Social and Ecological Systems: Management Practices and Social Mechanisms for Building Resilience, Cambridge (UK), Cambridge University Press.

Bransford J., Bixler R. and Hammitt W.E. (2006). South Florida Population Study: Volume Two. Comprehensive Everglades Restoration Plan: Familiarity and Attitudes, unpublished report prepared by the Department of Parks, Recreation and Tourism Management, Clemson, University for the National Park Service (February).

Busch D.E., Trexler J.C. (2003). The importance of monitoring in regional ecosystem initiatives, in: Monitoring Ecosystems: Interdisciplinary Approaches for Evaluating Ecoregional Initiatives, Busch D.E., Trexler J.C. (eds), Washington, DC, Island Press.

Clarke J.N., McCool D. (1996). Staking Out the Terrain: Power and Performance among Natural Resource Agencies, Albany, State University of New York Press.

Cole L. W., Foster S.R. (2001). From the Ground Up: Environmental Racism and the Rise of the Environmental Justice Movement, New York, New York University Press. 
Conway K. (2004). Statewide survey of 804 with an oversample of 100 SFWMD residents, unpublished report conducted by the Polling Company ${ }^{\mathrm{TM}}$ inc. for the South Florida Water Management District (June 2004).

Cortner H., Moote M. (1999). The Politics of Ecosystem Management, Washington, DC, Island Press.

(CROGEE) Committee on Restoration of the Greater Everglades Ecosystem (2003). Adaptive Monitoring and Assessment for the Comprehensive Everglades Restoration Plan, Washington, DC, National Academies Press.

Cumming G., Cumming D. and Redman C. (2006). Scale mismatches in socialecological systems: Causes, consequences, and solutions, Ecology and Society, vol. 11 , p. 14 .

Dennis S.N. (1988). When commissions go to court: A summary of favorable treatment of challenges to ordinances and commission decisions, Washington, DC, US Department of the Interior, National Park Service.

Dustin D., Schneider I. (1998). The widening circle: The role of democratic deliberation in outdoor recreation conflict management, Trends, vol. 35, pp. 27-30.

Ellen R. (1996). Introduction, in: Redefining Nature: Ecology, Culture and Domestication, Ellen R., Fukui K. (eds), Oxford, Berg.

Fairhead J., Leach M. (1996). Misreading the African Landscape: Society and Ecology in a Forest-savanna Mosaic, Cambridge, Cambridge University Press.

(GCSSF) Governor's Commission for a Sustainable South Florida (1995). The initial report of The Governor's Commission for a Sustainable South Florida, unpublished report available at www.state.fl.us/everglades/gcssflconcept/conc_tc.btml

(GCSSF) Governor's Commission for a Sustainable South Florida (1996). The conceptual plan of the Governor's Commission for a Sustainable South Florida, unpublished report available at www.state.fl.us/everglades/gcssflconcept/conc_tc.btml

Glicken J. (2000). Getting stakeholder participation "right": A discussion of participatory processes and possible pitfalls, Environmental Science and Policy, vol. 3, pp. 305-310.

Godelier M. (1986). Ecosystems and Social Systems, London, Verso.

Golley F.B. (1993). A History of the Ecosystem Concept in Ecology: More Than the Sum of the Parts, New Haven, CT, Yale University Press.

Gragson T., Grove M. (2006). Introduction: Social science in the context of the Long Term Ecological Research Program, Society and Natural Resources, vol. 19, pp. 93-100. 
Gregory R., McDaniels T. and Fields D. (2001). Decision adding, not dispute resolution: Creating insights through structured environmental decisions, Journal of Policy Analysis and Management, vol. 20, pp. 415-432.

Guha R. (1989). Unquite Woods: Ecological Change and Peasant Resistance in the Himalaya, Dehli, Oxford University Press.

Gunderson L.H. (2003). Foreword, in: Monitoring Ecosystems: Interdisciplinary Approaches for Evaluating Ecoregional Initiatives, Busch D.E., Trexler J.C. (eds), Washington, DC, Island Press.

Gunderson A.G. (1995). The Environmental Promise of Democratic Deliberation, Madison, WI, University of Wisconsin Press.

Hollander G. (2004). Agricultural trade liberalization, multifunctionality, and sugar in the South Florida landscape, Geoforum, vol. 35, pp. 299-312.

Holling C.S., Meffe G.K. (1996). Command and control and the pathology of natural resource management, Conservation Biology, vol. 10, pp. 328-337.

Jasanoff S. (2004). The idiom of co-production, in: States of Knowledge: The Co-production of Science and Social Order, London, Routledge.

Jorgensen S.E., Muller F. (eds) (2000). Handbook of Ecosystem Theories and Management, Boca Raton, FL, Lewis Publishers.

Kottack C.P. (1999). The new ecological anthropology, American Anthropologist, vol. 1(1), pp. 23-35.

Krannich R.S., Smith M.D. (1998). Local perceptions of public lands natural resource management in the rural West: Toward improved understanding of the "revolt in the West", Society and Natural Resources, vol. 11, pp. 667-695.

Lawrence R.L., Daniels S.E. (1996). Public Involvement in Natural Resource Decision Making: Goals, Methodology, and Evaluation, Corvallis, OR, Forestry Publication Office, Oregon State University.

Li T. (2005). Beyond the "State" and failed schemes, American Anthropologist, vol. 107, pp. 383-394.

McCally D. (1999). Everglades: An Environmental History, Gainesville, FL, University Press of Florida.

Milon J.W., Hodges A. (2000). Who wants to pay for Everglades restoration?, Choices, vol. 2, pp. 12-16.

Moore D. S. (2005). Suffering for Territory: Race, Place, and Power in Zimbabwe, Durham, NC, Duke University Press.

Moote M.A., McClaran M.P. (1997). Viewpoint: Implications of participatory democracy for public land planning, Journal of Environmental Management, vol. 50, pp. 473-481. 
Moote M.A., McClaran M.P. and Chickering D.K. (1997). Theory in practice: Applying participatory democracy theory to public land planning, Environmental Management, vol. 21, pp. 877-889.

Moran E.F. (1990). Ecosystem ecology in biology and anthropology: A critical assessment, in: The Ecosystem Approach in Anthropology, From Concept to Practice, Moran E.F. (ed.), Ann Arbor, MI, The University of Michigan Press.

Netting R.McC. (1990). Links and boundaries: Reconsidering the Alpine village as ecosystem, in: The Ecosystem Approach in Anthropology: From Concept to Practice, Moran E.F. (ed.), Ann Arbor, MI, The University of Michigan Press.

Neumann R. (2004). Nature-state-territory: Toward a critical theorization of conservation enclosures, in: Liberation Ecologies, Peet R., Watts M. (eds), London, Routledge.

Neumann R. (1989). Imposing Wilderness: Struggles Over Livelibood and Nature Preservation in Africa, Berkeley, University of California Press.

(NRC) National Research Council (2003). Science and the Greater Everglades Ecosystem Restoration: An Assessment of the Critical Ecosystem Studies Initiative, Washington, DC, The National Academies Press.

Ogden J.C. (1994). A comparison of wading birds nesting colony dynamics (19311946 and 1974-1989) as an indicator of ecosystem conditions of the Southern Everglades, in: Everglades: The Ecosystem and Its Restoration, Davis S.M., Ogden J.C. (eds), Delray Beach FL, St Lucie Press.

Ogden J.C., Davis S.M. and Brandt L.A. (2003). Science strategy for a regional ecosystem monitoring and assessment program: The Florida Everglades example, in: Monitoring Ecosystems: Interdisciplinary Approaches for Evaluating Ecoregional Initiatives, Busch D.E., Trexler J.C. (eds), Washington, DC, Island Press.

Ogden J.C., Davis S.M., Jacobs K.J., Barnes T. and Fling H.E. (2005). The use of conceptual ecological models to guide ecosystem restoration in South Florida, Wetlands, vol. 25(4), pp. 795-809.

Ogden L., Bhat M., Dustin D., Gladwin H., Lipartito K., Rivera C. and Taylor L. (2003). A public engagement handbook for the comprehensive Everglades restoration planning process, Miami, FL, National Park Service, Critical Ecosystems Studies Initiative Report.

Olwig K.R. (2001). Landscape as contested topos of place, community and self, in: Textures of Place: Exploring Humanist Geographies, Adams P.C., Hoelscher S. and Till K.E. (eds), Minneapolis, University of Minnesota Press.

Peluso N. (2003). Weapons of the wild: Strategic uses of violence and wildness in the rain forests of Indonesian Borneo, in: In Search of the Rain Forest, Slater C. (ed.), Durham, NC, Duke University Press. 
Peluso N. (1992). Rich Forest, Poor People: Resource Control and Resistance in Java, Berkeley, CA, University of California Press.

Rappaport R. (1990). Ecosystems, populations and people, in: The Ecosystem Approach in Anthropology: From Concept to Practice, Moran E.F. (ed.), Ann Arbor, MI, The University of Michigan Press.

Rappaport R. (1967). Pigs for the Ancestors: Ritual in the Ecology of a New Guinea People, New Haven, CT, Yale University Press.

Redman C.L., Grove J.M. and Kuby L.H. (2004). Integrating social science into the Long-Term Ecological Research (LTER) network: Social dimensions of ecological change and ecological dimensions of social change, Ecosystems, vol. 7, pp. 161-171.

Roberts P. (1999). The sweet hereafter: Florida's Everglades endangered by sugar industry, Harper's Magazine, November.

Shallat T. (1994). Structures in the Stream: Water, Science, and the Rise of the US Army Corps of Engineers, Austin, TX, University of Texas Press.

(SFERTF) South Florida Ecosystem Restoration Task Force (2005). Cross-Cut Budget: South Florida Ecosystem Restoration Program, Miami, FL, SFERTF.

(SFERTF) South Florida Ecosystem Restoration Task Force (2002). Coordinating Success: Strategy for Restoration of the South Florida Ecosystem, Miami, FL, SFERTF.

(SFERWG) South Florida Ecosystem Restoration Working Group (1999). South Florida Action Plan for Applied Behavioral Sciences, Coral Gables, FL, Governor's Commission for a Sustainable South Florida.

Simpson C.T. (1923). Out of Doors in Florida: The Adventures of a Naturalist, Together with Essays on the Wild Life and the Geography of the State, Miami, E. B. Douglas Company.

Small J.K. (1929). From Eden to Sahara: Florida's Tragedy, Lancaster, PA, The Science Press Printing Company.

Spooner B. (1987). Insiders and outsiders in Baluchistan: Western and indigenous perspectives on ecology and development, in: Lands at Risk in the Third World: Local Level Perspective, Little P.D., Horowitz M. (eds), Boulder, CO, Westview Press.

Steelman T. (2001). Elite and participatory policymaking: Finding a balance in a case of national forest planning, Policy Studies Journal, vol. 29(1), pp. 71-89.

Tebeau C.W. (1968). Man in the Everglades: 2000 Years of Human History in the Everglades National Park, Coral Gables, FL, University of Miami Press.

(USACE and SFWMD) US Army Corps of Engineers and South Florida Water Management District (1999). The Central and Southern Florida project comprehensive review study, final integrated feasibility report and 
programmatic environmental impact assessment, United States Army Corps of Engineers, Jacksonville District and South Florida Water Management District, West Palm Beach, FL.

Webler T., Tuler S. and Krueger R. (2001). What is a good public participation process? Five perspectives from the public, Environmental Management, vol. 3 , pp. $435-450$.

Williams R. (1980). Problems in Materialism and Culture, London, Verso.

Worster D. (1977). Nature's Economy: A History of Ecological Ideas, Cambridge, Cambridge University Press. 